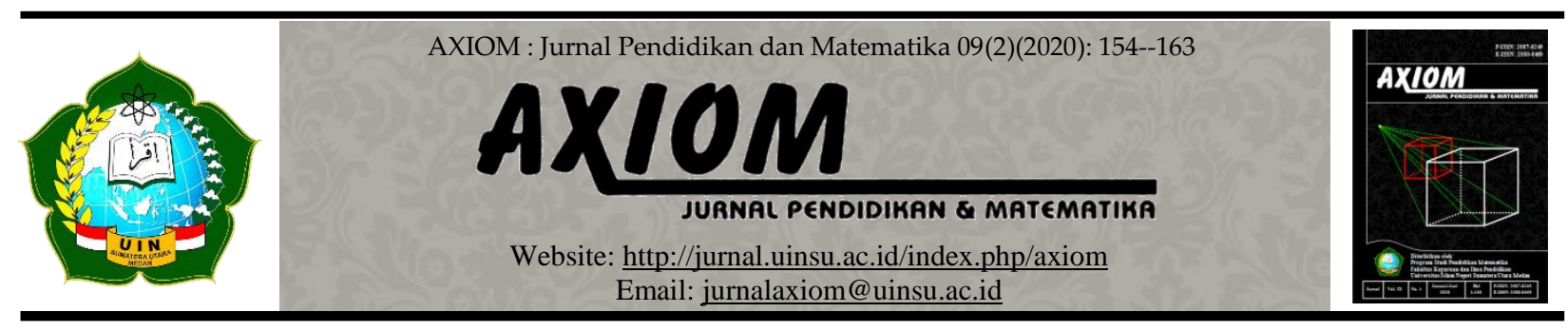

\title{
PERBEDAAN KEMAMPUAN PEMECAHAN MASALAH DAN KEMAMPUAN KOMUNIKASI MATEMATIS SISWA YANG DIAJAR MENGGUNAKAN MODEL PEMBELAJARAN NUMBERED HEAD TOGETHER DAN TEAMS GAMES TOURNAMENT
}

Oleh:

\author{
Fielia Aulina ${ }^{1}$, Eka Khairani Hasibuan ${ }^{2}$ \\ ${ }^{1}$ Pendidikan Matematika, Fakultas Ilmu Tarbiyah dan Keguruan, Universitas Islam Negeri \\ Sumatera Utara \\ ${ }^{2}$ Pendidikan Matematika, Fakultas Ilmu Tarbiyah dan Keguruan, Universitas Islam Negeri \\ Sumatera Utara \\ E-mail: ${ }^{1}$ fieliaaulina49@gmail.com, ${ }^{2}$ ekakhairani@uinsu.ac.id
}

doi : 10.30821/axiom.v9i2.7966

\begin{abstract}
Abstrak:
Tujuan penelitian ini adalah untuk melihat perbedaan kemampuan pemecahan masalah dan komunikasi matematis siswa yang diajar menggunakan model Numbered Head Together dan Teams Games Tournament. Penelitian ini berjenis penelitian kuantitatif dengan metode eksperimen. Sampel dari penelitian ini adalah kelas X-A dan X-B dengan kelas heterogen. Hasil temuan ini menunjukkan: 1) terdapat perbedaan kemampuan pemecahan masalah matematis siswa yang diajar menggunakan model pembelajaran Numbered Head Together dan Teams Games Tournament, dengan $\mathrm{Q}_{\mathrm{hit}}=3,167>\mathrm{Q}_{\text {tabel }}=2,871$; 2) terdapat perbedaan kemampuan komunikasi matematis siswa yang diajar menggunakan model pembelajaran Numbered Head Together dan Teams Games Tournament, dengan $\left.\mathrm{Q}_{\text {hit }}=8,189>\mathrm{Q}_{\text {tabel }}=2,871 ; 3\right)$ terdapat perbedaan kemampuan pemecahan masalah dan komunikasi matematis siswa yang diajarkan menggunakan model pembelajaran Numbered Head Together dan Teams Games Tournament pada materi sistem persamaan linear tiga variabel, dengan $F_{\text {hitung }}=32,42>F_{\text {tabel }}=4,12$. Simpulan penelitian ini adalah kemampuan pemecahan masalah dan komunikasi matematis siswa lebih sesuai diajarkan dengan model pembelajaran Numbered Head Together daripada Teams Games Tournament.
\end{abstract}

Kata Kunci:

Kemampuan Pemecahan Masalah, Komunikasi Matematis, Model Pembelajaran Numbered Head Together, Teams Games Tournament

\section{Abstract:}

The purpose of this study was to see the differences in problem solving and mathematical communication skills of students taught using the Numbered Head Together and Teams Games Tournament models. This research is a quantitative research by conducting experiments. The sample of this research is class $X-A$ and $X-B$ with heterogeneous classes. These findings indicate: 1) There are differences in students' mathematical problem solving abilities taught using the NHT and TGT learning models, with $Q_{h i t}=3,167>Q_{\text {tabel }}=2,871$;2) There are differences in students' mathematical communication skills taught using the NHT and TGT learning models, with $Q_{\text {hit }}=8,189>Q_{\text {tabel }}=2,871$; 3) There are differences in students' problem solving and 
mathematical communication skills taught using the NHT and TGT learning models on the material of the three-variable linear equation system, with $F_{\text {hitung }}=32,42>F_{\text {tabel }}=4,12$. The conclusion of this study explains that the problem solving ability and mathematical communication of students are more suitable to be taught using the NHT learning model than the TGT model

\section{Keywords:}

Problem Solving Skills, Mathematical Communication, Numbered Head Together, Teams Games Tournament Learning

\section{A. Pendahuluan}

Pendidikan yang berkualitas akan menjadikan sumber daya manusia cerdas dan mampu menjadikan Indonesia sebagai negara maju. Dalam kehidupan sehari-hari pendidikan sangat diperlukan karena pendidikan merupakan sarana untuk membentuk cita-cita bangsa dan masyarakat, yakni membentuk masyarakat yang cerdas dan berbudaya. Undang-Undang Nomor 20 Tahun 2003 tentang Sistem Pendidikan Nasional menegaskan bahwa pendidikan adalah usaha sadar dan terencana untuk mewujudkan suasana belajar dan proses pembelajaran agar peserta didik secara aktif mengembangkan potensi dirinya untuk memiliki kekuatan spiritual keagamaan, pengendalian diri, kepribadian, kecerdasan, akhlak mulia serta keterampilan yang diperlukan dirinya, masyarakat, bangsa dan negara.

Dalam proses pembelajaran, guru sebagai pengelola pembelajaran perlu memiliki kemampuan untuk merancang strategi pembelajaran yang dianggap cocok dengan minat dan bakat serta sesuai dengan tingkat perkembangan siswa. Salah satu mata pelajaran yang sering dijadikan alasan sebagai kesulitan siswa dalam proses pembelajaran adalah pelajaran matematika. Istimewanya matematika sebagai ilmu yang penting untuk dipelajari memiliki banyak alasan, seperti yang dinyatakan oleh Cocroft (dalam Mulyono, 2018) yaitu matematika perlu diajarkan kepada siswa karena: (1) selalu digunakan dalam segala kehidupan, (2) semua bidang studi memerlukan keterampilan matematika yang sesuai, (3) merupakan sarana komunikasi yang kuat, singkat dan jelas, (4) dapat digunakan untuk menyajikan informasi dalam berbagai cara, (5) meningkatkan kemampuan berpikir logis, ketelitian dan kesadaran ruangan, dan (6) memberikan kepuasan terhadap usaha memecahkan masalah yang menantang.

Dalam pembelajaran matematika pemecahan masalah merupakan inti pembelajaran yang merupakan kemampuan dasar dalam proses pembelajaran. Pemecahan masalah merupakan kemampuan yang harus dimiliki siswa dalam pembelajaran matematika. NCTM (2000) menyatakan bahwa seorang guru harus mampu mengubah siswa menjadi seorang pemecah masalah yang fleksibel dan cerdas. NCTM (2000) juga menyatakan bahwa pemecahan masalah tidak hanya menjadi tujuan belajar matematika, tetapi juga merupakan sarana utama untuk melakukan matematika itu sendiri. Kemampuan pemecahan masalah merupakan bagian terpenting dari proses yang terjadi dalam diri pelajar dan memecahkan masalah merupakan proses dalam menerima tantangan untuk menjawab masalah. Polya (1973) berpendapat bahwa pemecahan masalah merupakan usaha mencari jalan keluar dari suatu kesulitan untuk mencapai tujuan yang ingin segera dicapai.

Selain kemampuan pemecahan masalah, juga terdapat kemampuan komunikasi matematis yang sangat penting untuk dikuasai. Dalam Peraturan Menteri Pendidikan Nasional No. 22 Tahun 2006 tentang Standar Isi, untuk satuan pendidikan dasar dan menengah mata pelajaran matematika disebutkan bahwa salah satu tujuan pembelajaran matematika adalah agar siswa memiliki kemampuan mengkomunikasikan gagasan dengan simbol, tabel, diagram, atau media lain untuk memperjelas keadaaan atau masalah. Tujuan permendiknas ini, sejalan dengan tujuan umum pembelajaran matematika yang dirumuskan NCTM (2000) bahwa salah satu tujuan pembelajaran matematika adalah belajar untuk berkomunikasi (mathematical communication).

Berdasarkan tujuan NCTM (2000) bahwa kemampuan pemecahan masalah dan komunikasi matematis sangat penting untuk dikembangkan, terlebih lagi dalam pelajaran matematika. Namun, kenyataan berdasarkan hasil observasi awal di sekolah MAS Al-Ulum 
Medan pada tanggal 20 Januari 2020, siswa di sekolah tersebut masih sangat banyak yang tidak menyukai pelajaran matematika, mereka mengatakan bahwa matematika itu sulit untuk dipahami, terlalu banyak rumus, dan sangat membosankan. Pandangan siswa seperti inilah yang mempengaruhi rendahnya kemampuan pemecahan masalah matematis siswa. Hal ini menunjukkan bahwa kemampuan pemecahan masalah siswa di sekolah tersebut masih sangat rendah. Rendahnya kemampuan pemecahan masalah matematis siswa juga dikarenakan kegiatan pembelajaran yang masih berpusat pada guru dan penggunaan pendekatan pembelajaran yang masih kurang relevan. Ada juga siswa yang mengalami kesulitan dalam menyampaikan ide ataupun gagasan yang mereka miliki di dalam kelas pada saat kegiatan pembelajaran berlangsung. Ini dikarenakan sebagian siswa masih kesulitan dalam memahami suatu persoalan yang tertera dalam soal, sehingga siswa mengalami kesulitan dalam menginterpretasikan soal tersebut. Kondisi ini mempengaruhi terhadap kemampuan komunikasi matematis siswa, sehingga siswa mengalami kesulitan ketika membaca atau menginterpretasikan suatu data yang berbentuk gambar, grafik, dan notasi matematika yang lainnya.

Salah satu model pembelajaran yang dapat menjadi pilihan dan diduga dapat meningkatkan kemampuan pemecahan masalah dan komunikasi matematis siswa dalam pembelajaran matematika adalah model pembelajaran kooperatif tipe Numbered Head Together (NHT) dan Teams Games Tournament (TGT). Risnaldi (2006) menyatakan bahwa penerapan teknik Numbered Head Together memberikan dampak positif yaitu antusiasme siswa dalam belajar bisa lebih tinggi, lebih mudah dalam menyelesaikan pertanyaan sulit, dan lebih tertarik dalam kerja kelompok. Sedangkan Sohimin (2016) mengatakan bahwa aktivitas belajar dengan permainan yang dirancang dalam pembelajaran kooperatif model TGT memungkinkan siswa dapat belajar lebih rilekas di samping menumbuhkan tanggung jawab, kerja sama, persaingan sehat dan keterlibatan belajar.

Berdasarkan permasalahan di atas maka akan dilakukan penelitian dengan judul "Perbedaan Kemampuan Pemecahan Masalah dan Kemampuan Komunikasi Matematis Siswa Yang Diajar Menggunakan Model Pembelajaran Numbered Head Together Dan Teams Games Tournament Di Kelas X MAS Al-Ulum, Medan".

\section{B. Kajian Teoritis}

\section{Kemampuan Pemecahan Masalah}

Ismawati (2017) mengemukakan bahwa kemampuan pemecahan masalah amatlah penting bukan saja bagi mereka yang kemudian hari akan mendalami matematika, melainkan juga bagi mereka yang akan menerapkannya dalam bidang studi lain maupun kehidupan seharihari'. Selain itu Rezeki (2012) menyatakan bahwa kemampuan pemecahan masalah adalah komponen penting dalam pembelajaran matematika, dalam kemampuan tersebut siswa akan mempunyai kemampuan dasar yang bermakna lebih. Menurut Polya (1973), pemecahan masalah adalah sebuah proses yang memerlukan logika dalam rangka mencari solusi dari suatu permasalahan. Kemampuan pemecahan masalah dapat dimiliki oleh siswa apabila guru mengajarkannya dengan efektif. Terdapat empat tahap pemecahan masalah, yaitu: (1) understood the problem (memahami masalah), (2) device a plan (menyusun rencana pemecahan masalah), (3) carry out the plan (melaksanakan rencana pemecahan masalah), dan (4) look back (memeriksa kembali hasil yang diperoleh). Polya (1973), secara operasional pemecahan masalah memiliki tahap-tahap: (1) memahami masalah, (2) merencanakan pemecahannya, (3) menyelesaikan masalah sesuai dengan rencana (4) memeriksa kembali prosedur dan hasil penyelesaian.

Untuk mengetahui sejauh mana kemampuan pemecahan masalah matematika yang di miliki siswa, dapat diukur dengan berpedoman pada indikator: (a) Memahami masalah, yaitu mengidentifikasi kecukupan data untuk menyelesaikan masalah sehingga memperoleh gambaran lengkap apa yang diketahui dan ditanyakan dalam masalah tersebut. (b) Merencanakan penyelesaian, yaitu menetapkan langkah-langkah penyelesaian, pemilihan konsep, persamaan 
dan teori yang sesuai untuk setiap langkah. (c) Menjalankan rencana, yaitu menjalankan penyelesaian berdasarkan langkah -langkah yang telah dirancang dengan menggunakan konsep, persamaan serta teori yang dipilih. (d) Melihat kembali apa yang telah dikerjakan yaitu tahap pemeriksaan, apakah langkah-langkah penyelesaian telah terealisasikan sesuai rencana sehingga dapat memeriksa kembali kebenaran jawaban yang pada akhirnya membuat kesimpulan akhir.

\section{Kemampuan Komunikasi Matematis}

NCTM (2000) menyatakan bahwa kemampuan komunikasi matematis merupakan kemampuan untuk mengorganisasi pikiran matematika, mengkomunikasikan gagasan matematika secara logis dan jelas kepada orang lain, menganalisis dan mengevaluasi pikiran matematika dan strategi yang digunakan orang lain, dan menggunakan bahasa matematika untuk menyatakan ide-ide secara tepat. Menurut Baroody (dalam Hodiyanto, 2017), terdapat dua alasan penting mengapa komunikasi menjadi salah satu fokus dalam pembelajaran matematika. Pertama, matematika pada dasarnya adalah sebuah bahasa bagi matematika itu sendiri. Matematika tidak hanya merupakan alat berpikir yang membantu kita untuk menemukan pola, memecahkan masalah dan menarik kesimpulan, tetapi juga sebuah alat untuk mengomunikasikan pikiran kita tentang berbagai ide dengan jelas, tepat dan ringkas. Bahkan, matematika dianggap sebagai bahasa universal dengan simbol-simbol dan struktur yang unik. Semua orang di dunia dapat menggunakannya untuk mengomunikasikan informasi matematika meskipun bahasa asli mereka berbeda.

Kedua, belajar dan mengajar matematika merupakan aktivitas sosial yang melibatkan paling sedikit dua pihak, yaitu guru dan murid. Menurut Prayitno dkk. (2013) komunikasi matematis adalah suatu cara siswa untuk menyatakan dan menafsirkan gagasan-gagasan matematika secara lisan maupun tertulis, baik dalam bentuk gambar, tabel, diagram, rumus, ataupun demonstrasi. Pengertian yang lebih luas tentang komunikasi matematik dikemukakan oleh Romberg dan Chair (dalam Qahar, 2011), yaitu menghubungkan benda nyata, gambar, dan diagram ke dalam idea matematika; menjelaskan idea, situasi dan relasi matematik secara lisan atau tulisan dengan benda nyata, gambar, grafik dan aljabar; menyatakan peristiwa sehari hari dalam bahasa atau simbol matematika; mendengarkan, berdiskusi, dan menulis tentang matematika; membaca dengan pemahaman suatu presentasi matematika tertulis, membuat konjektur, menyusun argumen, merumuskan definisi dan generalisasi; menjelaskan dan membuat pertanyaan tentang matematika yang telah dipelajari.

Kadir (2017) menjelaskan bahwa untuk mengungkap kemampuan siswa dalam berbagai aspek komunikasi, dapat dilakukan dengan melihat kemampuan siswa dalam mendiskusikan masalah dan membuat ekspresi matematika secara tertulis baik gambar, model matematika, maupun simbol atau bahasa sendiri. Lebih lanjut Kadir (dalam Hodiyanto, 2017) mengungkapkan bahwa pengukuran kemampuan komunikasi matematis siswa dilakukan dengan memberikan skor terhadap kemampuan siswa dalam memberikan jawaban soal dengan menggambar (drawing), membuat ekspresi matematik (mathematical expression), dan menuliskan jawaban dengan bahasa sendiri (written texts). Pemberian skor jawaban siswa disusun berdasarkan tiga kemampuan tersebut. (a) Menulis (written text), yaitu menjelaskan ide atau solusi dari suatu permasalahan atau gambar dengan menggunakan bahasa sendiri. (b) Menggambar (drawing), yaitu menjelaskan ide atau solusi dari permasalahan matematika dalam bentuk gambar. (c) Ekspresi matematika (matematical ekpression), yaitu menyatakan masalah atau peristiwa seharihari dalam bahasa model matematika.

Dalam proses belajar dan mengajar, sangat penting mengemukakan pemikiran dan gagasan itu kepada orang lain melalui bahasa. Pada dasarnya pertukaran pengalaman dan ide ini merupakan proses mengajar dan belajar. Tentu saja, berkomunikasi dengan teman sebaya sangat penting untuk pengembangan keterampilan berkomunikasi sehingga dapat belajar berfikir seperti seorang matematikawan dan berhasil menyelesaikan masalah yang benar-benar baru. 


\section{Model Pembelajaran Numbered Head Together (NHT)}

Menurut Davidson \& Kroll (dalam Sulfiani, 2016) dalam pembelajaran kooperatif siswa tidak hanya dituntut untuk secara individual berupaya mencapai sukses atau berusaha mengalahkan rekan mereka, melainkan dituntut dapat bekerjasama untuk mencapai hasil bersama, aspek sosial sangat menonjol dan siswa dituntut untuk bertanggungjawab terhadap keberhasilan kelompoknya. Model pembelajaran yang dapat membuat siswa terlibat dalam pelajaran dan memberikan suasana yang menyenangkan, sehingga siswa tidak merasa bosan selama pelajaran berlangsung adalah dengan penerapan suatu model pembelajaran yaitu model pembelajaran kooperatif adalah Tipe Numbered Head Together (NHT). Model NHT pada dasarnya merupakan varian diskusi kelompok, memberikan kesempatan kepada Siswa untuk membagikan ide dan mempertimbangkan jawaban yang paling tepat serta mendorong Siswa untuk meningkatkan semangat kerjasama mereka. Selain itu model pembelajaran NHT memiliki beberapa keistimewaan, ditinjau dari segi proses, penerapan NHT lebih mudah dilakukan dibandingkan dengan model kooperatif Tipe lainnya.

Numbered Head Together (NHT) memiliki empat tahap pembelajaran, yaitu: (1) penomoran, (2) pengajuan pertanyaan, (3) berpikir bersama, (4) menjawab. Menurut Huda (dalam Mulyana 2016), yang mengemukakan model pembelajaran kooperatif tipe NHT sebagai berikut: (a) Dikembangkan oleh Russ Frank. (b) Memberikan kesempatan kepada siswa untuk saling sharing ide-ide dan mempertimbangkan jawaban yang paling tepat. (c) Meningkatkan semangat kerjasama siswa. Dapat digunakan untuk semua mata pelajaran dan tingkatan kelas. Risnaldi (2016) menyatakan bahwa penerapan teknik Numbered Heads Together memberian dampak positif yaitu antusiasme siswa dalam belajar bisa lebih tinggi, lebih mudah dalam menyelesaikan pertanyaan sulit, dan lebih tertarik dalam kerja kelompok. Wora (dalam Arsitarasmi, 2017) juga menyatakan bahwa penerapan model pembelajaran NHT meningkatkan keterlibatan dalam kegiatan pembelajaran serta tingkat pencapaian prestasinya. Beberapa langkah model pembelajaran Numbered Head Together (NHT) sebagai berikut: (a) Siswa dibagi dalam kelompok. Setiap siswa dalam setiap kelompok mendapat nomor. (b) Guru memberikan tugas dan masing-masing kelompok mengerjakannya. (c) Kelompok mendiskusikan jawaban yang benar dan memastikan tiap anggota kelompok dapat mengerjakannya/mengetahui jawabannya yang baik. (d) Guru memanggil salah satu nomor siswa dan nomor yang dipanggil keluar dari kelompoknya melaporkan atau menjelaskan hasil kerja sama mereka. (e) Tanggapan dengan teman yang lain, kemudian guru menunjuk nomor yang lain. (f) Kesimpulan.

Adapun kelebihan dari pembelajaran Kooperatif Tipe Numbered Head Together (NHT) yaitu: (a) Setiap murid menjadi siap. (b) Dapat melakukan dengan sungguh-sungguh. (c) Murid yang pandai dapat mengajari murid yang kurang pandai. (d) Terjadi interaksi secara intens antarsiswa dalam menjawab soal. (e) Tidak ada murid yang mendominasi dalam kelompok karena ada nomor yang membatasi. Selain kelebihan, juga ada kekurangan model pembelajaran Numbered Head Together (NHT) yaitu: (a) Tidak terlalu cocok diterapkan dalam jumlah siswa banyak karena membutuhkan waktu yang lama. (b) Tidak semua anggota kelompok dipanggil oleh guru karena kemungkinan waktu yang terbatas

\section{Model Model Pembelajaran Teams Games Tournament (TGT).}

Menurut Yolagel dili dan Arikan (dalam Soleh, 2017), jika dalam permainan minat siswa dapat terangsang melalui aktivitas siswa di kelas sehingga dapat menumbuhkan motivasi dan minat untuk belajar. Sehingga dapat diharapkan melalui permainan akademik pada model pembelajaran TGT hasil belajar dan aktivitas siswa dapat meningkat. Menurut Aris Sohimin (2016) aktivitas belajar dengan permainan yang dirancang dalam pembelajaran kooperatif model TGT memungkinkan siswa dapat belajar lebih rileks di samping menumbuhkan tanggung jawab, kerja sama, persaingan sehat, dan keterlibatan belajar. Menurut Slavin (2012), pembelajaran Kooperatif tipe TGT terdiri dari llima langkah tahapan, yaitu tahap penyajian kelas (class 
precentation), belajar dalam kelompok (teams), permainan (games), pertandingan (tournament), dan penghargaan kelompok (team recognition).

Berdasarkan apa yang diungkapkan oleh Slavin (2012), maka model pembelajaran kooperatif tipe TGT memiliki ciri-ciri sebagai berikut: (a) Siswa bekerja dalam kelompokkelompok kecil, (b) Game tournament, (c) Penghargaan kelompok. Adapun beberapa langkahlangkah model pembelajaran Teams Games Tournament (TGT) sebagai berikut: (a) Penyajian Awal, (b) Belajar dalam kelompok, (c) Permainan, (d) Pertandingan atau lomba, dan (e) Penghargaan Kelompok. Adapun kelebihan dari pembelajaran Teams Games Tournament (TGT), yaitu: (a) Model TGT tidak hanya membuat peserta didik yang cerdas (berkemampuan akademis tinggi) lebih menonjol dalam pembelajaran, tetapi peserta didik yang berkemampuan akademi lebih rendah juga ikut aktif dan mempunyai peranan penting dalam kelompoknya. (b) Dengan model pembelajaran ini, akan menumbuhkan rasa kebersamaan dan saling menghargai sesama anggota kelompoknya. (c) Dalam model pembelajaran ini, membuat peserta didik lebih bersemangat dalam mengikuti pelajaran. Karena dalam pembelajaran ini, guru menjanjikan sebuah penghargaan pada peserta didik atau kelompok terbaik. (d) Dalam pembelajaran peserta didik ini, membuat peserta didik menajdi lebih senang dalam mengikuti pelajaran karena ada kegiatan permainan berupa turnamen dalam model ini. Kekurangan model pembelajaran Teams Games Tournament (TGT), yaitu: (1) Membutuhkan waktu yang lama. (2) Guru dituntut untuk pandai memilih materi pelajaran yang cocok untuk model ini. (3) Guru harus mempersiapkan model ini dengan baik sebelum diterapkan. Misalnya, membuat soal untuk setiap meja turnamen atau lomba, dan guru harus tahu urutan akademis peserta didik dari yang tertinggi hingga terendah.

\section{Metode Penelitian}

1. Jenis Penelitian

Penelitian ini berjenis penelitian kuantitatif yang menggunakan penelitian eksperimen. Sebab kelas yang digunakan telah terbentuk sebelumnya.

\section{Lokasi dan Waktu Penelitian}

Nama Sekolah adalah Madrasah Aliyah Swasta Plus Al-Ulum, Medan. Beralamat di jalan Puri No.154, Kecamatan Medan Area. Kota Medan, Provinsi Sumatera Utara. Sekolah ini memiliki akreditasi A. Sekolah tersebut memiliki 301 siswa. Pada kelas X terdapat 107 siswa, kelas XI terdapat 118 siswa dan kelas XII terdapat 76 siswa.

\section{Sampel Penelitian}

Sampel Penelitian ini memakai kelas X-A untuk kelompok pembeajaran NHT dan Kelas X-B untuk kelompok pembelajaran TGT yang berjumlah 35 siswa perkelas.

\section{Prosedur}

Prosedur penelitian ini menggunakan desain faktorial dengan taraf 2x2. Dalam desain ini masing-masing variabel bebas diklasifikasikan menjadi 2 (dua) sisi, yaitu model Pembelajaran NHT $\left(\mathrm{A}_{1}\right)$ dan TGT $\left(\mathrm{A}_{2}\right)$. Sedangkan variabel terikatnya diklasifikasikan menjadi kemampuan pemecahan masalah $\left(\mathrm{B}_{1}\right)$ dan kemampuan komunikasi matematis $\left(\mathrm{B}_{2}\right)$.

\section{Tabel 1. Desain Penelitian}

\begin{tabular}{lcc}
\hline \multicolumn{1}{c}{ Kemampuan } & Pembelajaran NHT $\left(\mathrm{A}_{1}\right)$ & Pembelajaran TGT $\left(\mathrm{A}_{2}\right)$ \\
\hline Berpikir pemecahan masalah $\left(\mathrm{B}_{1}\right)$ & $\mathrm{A}_{1} \mathrm{~B}_{1}$ & $\mathrm{~A}_{2} \mathrm{~B}_{1}$ \\
Pemecahan komunikasi $\left(\mathrm{B}_{2}\right)$ & $\mathrm{A}_{1} \mathrm{~B}_{2}$ & $\mathrm{~A}_{2} \mathrm{~B}_{2}$ \\
\hline
\end{tabular}

\section{Data, Intrumen, dan Teknik Pengumpulan Data}

Dalam penelitian ini terdiri dari tiga tahap, yaitu : 1) Tahap Perencanaan (Pemilihan subjek penelitian, Menyusun kisi-kisi soal tes yang sesuai dengan indikator kemampuan 
pemecahan masalah dan komunikasi, Validasi instrumen, dilakukan kepada pakar atau dosen senior dan siswa) 2) Tahap Pelaksanaan Penelitian (tes yang mengacu pada indikator kemampuan pemecahan masalah dan komunikasi; 3) Tahap Pelaporan (analisis data dan pembahasan untuk diambil suatu kesimpulan dari hasil penelitian).

\section{Teknik Analisis Data}

Teknik analisis data yang digunakan dalam penelitian ini meliputi reduksi data, penyajian data, perhitungan statistika deskripstif dan penarikan kesimpulan/verifikasi. Teknik yang tepat untuk mengumpulkan data kemampuan pemecahan masalah dan kemampuan komunikasi matematis siswa adalah melalui tes. Oleh sebab itu teknik pengumpulan data dalam penelitian ini adalah menggunakan tes untuk kemampuan pemecahan masalah dan kemampuan komunikasi matematis siswa. Kedua tes tersebut diberikan kepada semua siswa pada kelompok pembelajaran NHT dan kelompok Pembelajaran TGT. Adapun teknik pengambilan data adalah sebagai berikut: (a) Memberikan postes untuk memperoleh data kemampuan pemecahan masalah dan kemampuan komunikasi matematis siswa pada kelas eksperimen.(b) Melakukan analisis data postes yaitu uji normalitas, uji homogenitas pada kelas NHT dan kelas TGT. (c) Melakukan analisis data postes yaitu uji hipotesis dengan menggunakan teknik Analisis Varian lalu dilanjutkan dengan Uji tukey.

\section{Hasil Penelitian dan Pembahasan}

\section{Hasil}

Dari hasil penelitian yang telah dilakukan dikelas X MAS AL-ULUM Medan, akan menghasilkan data dari hasil jawaban siswa pada tes kemampuan pemecahan masalah dan komunikasi matematis siswa. Di bawah ini adalah hasil dan deskripsinya sebagai berikut:

Tabel 2. Hasil Data

\begin{tabular}{|c|c|c|c|}
\hline Sumber Statistik & $A_{1}($ NHT $)$ & $A_{2}($ TGT) & Jumlah \\
\hline \multirow[t]{6}{*}{$\mathrm{B}_{1}(\mathrm{PM})$} & $\mathrm{n}=35$ & $\mathrm{n}=35$ & $\mathrm{n}=70$ \\
\hline & $\sum X=2662$ & $\sum X=2468$ & $\sum X=5130$ \\
\hline & $\sum X^{2}=205836$ & $\sum X^{2}=177946$ & $\sum X^{2}=383782$ \\
\hline & $\mathrm{Sd}=9,959$ & $\mathrm{Sd}=10,733$ & $\mathrm{Sd}=10,65$ \\
\hline & Var $=99,173$ & $\operatorname{Var}=115,198$ & $\operatorname{Var}=113,424$ \\
\hline & Mean $=76,06$ & Mean $=70,51$ & Mean $=73,29$ \\
\hline \multirow[t]{6}{*}{$\mathrm{B}_{2}(\mathrm{KM})$} & $\mathrm{n}=35$ & $\mathrm{n}=35$ & $\mathrm{n}=70$ \\
\hline & $\sum X=2592$ & $\sum X=2084$ & $\sum X=4676$ \\
\hline & $\sum X^{2}=195348$ & $\sum X^{2}=128172$ & $\Sigma X^{2}=323520$ \\
\hline & $\mathrm{Sd}=9,988$ & $\mathrm{Sd}=10,961$ & $\mathrm{Sd}=12,719$ \\
\hline & $\operatorname{Var}=99,761$ & $\operatorname{Var}=120,138$ & $\operatorname{Var}=161,786$ \\
\hline & Mean $=74,06$ & Mean $=59,54$ & Mean $=66,80$ \\
\hline \multirow[t]{6}{*}{ Jumlah } & $\mathrm{n}=70$ & $\mathrm{n}=70$ & $\mathrm{n}=140$ \\
\hline & $\sum X=5254$ & $\sum X=4552$ & $\sum X=9806$ \\
\hline & $\sum X^{2}=401184$ & $\sum X^{2}=306118$ & $\sum X^{2}=707302$ \\
\hline & $\mathrm{Sd}=9,952$ & $\mathrm{Sd}=12,103$ & $\mathrm{Sd}=12,133$ \\
\hline & $\operatorname{Var}=99,04$ & $\operatorname{Var}=146,492$ & $\operatorname{Var}=147,207$ \\
\hline & Mean $=75,06$ & Mean $=65,03$ & Mean $=70,04$ \\
\hline
\end{tabular}


Tabel 3. ANAVA

\begin{tabular}{lccccc}
\hline Sumber Varians & Dk & JK & RJK & F Hitung $_{n}$ & $\mathbf{F}_{\text {Tabel }}$ \\
\hline Antar Kolom (A): & 1 & 3520,03 & 3520,03 & $32,42^{* * *}$ & \\
Antar Baris (B): & 1 & 1472,26 & 1472,26 & $13,56 * * *$ & 4,12 \\
Interaksi (A x B) & 1 & 704,26 & 704,26 & $6,49 * *$ & \\
Antar Kelompok A dan B & 3 & 5696,54 & 1898,85 & & 2,87 \\
Dalam Kelompok (Antar Sel) & 136 & 14765,20 & 108,57 & & \\
\hline Total Reduksi & 139 & 20461,74 & & & \\
\hline
\end{tabular}

Tabel 4. Uji Tukey

\begin{tabular}{|c|c|c|c|}
\hline $\begin{array}{c}\text { Pasangan kelompok yang } \\
\text { dibandingkan }\end{array}$ & $\mathbf{Q}_{\text {hitung }}$ & $\begin{array}{l}Q_{\text {tabel }} \\
\mathbf{0 , 0 5}\end{array}$ & Kesimpulan \\
\hline $\mathrm{Q}_{1 \text { (A1 dan A2) }}$ & 8,053 & 2,814 & Signifikan \\
\hline $\mathrm{Q}_{2(\mathrm{~B} 1 \mathrm{dan} \mathrm{B} 2)}$ & 5,208 & & Signifikan \\
\hline $\mathrm{Q}_{3}(\mathrm{~A} 1 \mathrm{~B} 1 \mathrm{dan} \mathrm{A} 2 \mathrm{~B} 1)$ & 3,167 & 2,871 & Signifikan \\
\hline $\mathrm{Q}_{4(\mathrm{~A} 1 \mathrm{~B} 2 \mathrm{dan} \mathrm{A} 2 \mathrm{~B} 2)}$ & 8,189 & & Signifikan \\
\hline $\mathrm{Q}_{5}(\mathrm{~A} 1 \mathrm{~B} 1 \mathrm{dan} \mathrm{A} 1 \mathrm{~B} 2)$ & 3,288 & & Tidak Signifikan \\
\hline $\mathrm{Q}_{6}(\mathrm{~A} 2 \mathrm{~B} 1 \mathrm{dan} \mathrm{A} 2 \mathrm{~B} 2)$ & 5,984 & & Signifikan \\
\hline $\mathrm{Q}_{7 \text { (A1B1 dan A2B2) }}$ & 9,330 & & Signifikan \\
\hline $\mathrm{Q}_{8(\mathrm{~A} 2 \mathrm{~B} 1 \mathrm{dan} \mathrm{A} 1 \mathrm{~B} 2)}$ & 3,163 & & Signifikan \\
\hline
\end{tabular}

Berdasarkan data diatas, Siswa yang memiliki kemampuan pemecahan masalah dan komunikasi matematis lebih sesuai diajarkan dengan model Pembelajaran Numbered Head Together daripada model Teams Games Tournament.

\section{Pembahasan}

Pada bagian ini diuraikan deskripsi dan interpretasi data hasil penelitian. Deskripsi dan interpretasi dilakukan terhadap kemampuan pemecahan masalah dan kemampuan komunikasi matematis siswa yang diajar dengan model pembelajaran Numbered Head Together dan siswa yang diajar dengan model pembelajaran Teams Games Tournament sebagai berikut

a. Terdapat perbedaan kemampuan pemecahan masalah matematis siswa yang diajar dengan model pembelajaran Numbered Head Together lebih baik daripada siswa yang diajar dengan model Teams Games Tournament pada materi Sistem Persamaan Linear Tiga Variabel di kelas X MAS Al-Ulum Medan. Dengan adanya nilai rata-rata kemampuan pemecahan masalah matematis siswa yang diajar menggunakan pembelajaran Numbered Head Together yaitu 76,06, sedangkan kemampuan pemecahan masalah matematis siswa yang diajar diajar menggunakan pembelajaran Teams Games Tournament adalah 70,51.

b. Terdapat perbedaan kemampuan komunikasi matematis siswa yang diajar dengan model pembelajaran Numbered Head Together lebih baik daripada siswa yang diajar dengan model pembelajaran Teams Games Tournament pada materi Sistem Persamaan Linear Tiga Variabel di kelas X MAS Al-Ulum Medan. Dengan adanya nilai rata-rata kemampuan komunikasi matematis siswa yang diajar menggunakan pembelajaran Numbered Head Together yaitu 74,06, sedangkan kemampuan komunikasi matematis siswa yang diajar diajar menggunakan pembelajaran Teams Games Tournament adalah 59,54.

c. Terdapat perbedaan kemampuan pemecahan masalah dan kemampuan komunikasi matematis siswa yang diajar dengan model pembelajaran Numbered Head Together lebih baik daripada siswa yang diajar dengan model Teams Games Tournament pada materi 
Fielia Aulina \& Eka Khairani Hasibuan: Perbedaan Kemampuan Pemecahan Masalah dan Kemampuan Komunikasi Matematis Siswa yang Diajar Menggunakan Model Pembelajaran Numbered Head Together dan Teams Games Tournament

Sistem Persamaan Linear Tiga Variabel di kelas X MAS Al-Ulum Medan. Dapat dilihat dari besarnya $\mathrm{Q}_{\text {Hitung }}\left(\mathrm{A}_{1}, \mathrm{~A}_{2}, \mathrm{~B}_{1}\right.$ dan $\left.\mathrm{B}_{2}\right)$ atau pada $\mathrm{Q}_{1}(8,053) \mathrm{Q}_{2}(5,208)>$ dari $\mathrm{Q}_{\text {tabel }}(2,814)$.

d. Terdapat interaksi antara pembelajaran yang digunakan terhadap kemampuan pemecahan masalah dan kemampuan komunikasi matematis siswa. Dapat dilihat pada tabel ANAVA bahwa $\mathrm{F}_{\text {hitung }}$ Interaksi $(6,49)>\mathrm{F}_{\text {tabel }}(4,12)$.

\section{E. Simpulan}

Terdapat perbedaan kemampuan pemecahan masalah matematis siswa yang diajar dengan model pembelajaran Numbered Head Together dan Teams Games Tournament. Terdapat perbedaan kemampuan komunikasi matematis siswa yang diajar dengan model pembelajaran Numbered Head Together dan Teams Games Tournament. Terdapat perbedaan kemampuan pemecahan masalah dan komunikasi matematis siswa yang diajar dengan model pembelajaran Numbered Head Together dan Teams Games Tournament pada materi Sistem Persamaan Linear Tiga Variabel di kelas X MAS Al-Ulum Medan.

\section{DAFTAR PUSTAKA}

Arsitarasmi, R.D., Sadiman, S., \& Hadiyah, H. (2018). Implementation of numbered heads together (NHT) model based on audio visual media to improve concepts comprehension of cooperative. Social, Humanities, and Educational Studies (SHEs): Conference Series, $1(1), 719-723$.

Depdiknas. (2003). Undang-undang RI nomor 20 tahun 2003 tentang sistem pendidikan nasional. Jakarta: Depdiknas.

Depdiknas. (2006). Permendiknas nomor 22 tahun 2006 tentang standar isi. Jakarta: Depdiknas.

Hodiyanto. (2017). Kemampuan komunikasi matematis dalam pembelajaran matematika. Jurnal. Pontianak: IKIP PGRI, 7(1), 9-18. http://dx.doi.org/10.12928/admathedu.v7i1.7397

Ismawati, D. Y. (2014). Perbedaan Kemampuan Pemecahan Masalah Matematis Siswa Menggunakan Pendekatan Diskursif Metode Two Stay Two Stray Dengan Pembelajaran Konvensional (Skripsi). Universitas Pendidikan Indonesia, Bandung.

Kadir. (2008). Kemampuan Komunikasi Matematik dan Keterampilan Sosial Siswa Dalam Pembelajaran Matematika. Seminar Nasional Matematika dan Pendidikan Matematika pp. 339-350. UNY: Yogyakarta.

Mulyana, Mutia Agisni. (2016). Penerapan Model Pembelajaran Kooperatif Tipe Numbered Heads Together Untuk Meningkatkan Hasil Belajar Mata Pelajaran Matematika. Skripsi UPI Bandung.

Mulyono, Abdurrahman. (2018). Pendidikan bagi anak berkesulitan belajar. Jakarta: Rineka Cipta.

NCTM. (2000). Principles and Standards for School Mathematics. United States of America: The National Council of Teachers of Mathematics.

Polya, George. (1973). How to solve it: A new aspect of mathematical method (2nd ed.). New Jersey: Princeton University Press.

Prayitno, S., Suwarsono, \& Siswono, T. Y. (2013). Identifikasi Indikator Kemampuan Komunikasi Matematis Siswa dalam Menyelesaikan Soal Matematika Berjenjang pada Tiap-Tiap Jenjangnya. Konferensi Nasional Pendidikan Matematika V. Universitas Negeri Malang Tanggal 27-30 Juni 2013.

Qohar, A. (2011). Pengembangan instrumen komunikasi matematis untuk siswa SMP. Lomba dan Seminar Matematika XIX. UNY: Yogyakarta.

Rezeki, Dinda Putri. (2012). Analisis Perbedaan Kemampuan Berpikir Kreatif dan Pemecahan Masalah Matematika Antara Siswa Yang di Beri Pembelajaran Open-Ended dengan Pembelajaran Konvensional. Tesis. Medan: Program Pasca Sarjana Unimed. 
Risnaldi, F., Usman, B., \& Diana. (2016). Numbered heads together technique on improving students' reading comprehension. Journal of Research in English and Education, 1(2)

Shoimin, Aris. 2016. 68 Model pembelajaran inovatif. Yogyakarta: Ar-Ruzz Media.

Slavin, Robert E. 2005. Cooperating learning. Bandung: Nusa Media.

Soleh, Maulana Ibnu. 2017. Penerapan model pembelajaran kooperatif tipe teams games tournament (TGT) pada pembelajaran PIPS untuk meningkatkan hasil belajar siswa pada materi sumber daya alam dan kegiatan ekonomi. Jurnal Pena Ilmiah, 2(1), 2101-2110.

Sulfiani, Ridha. 2016. Penerapan model pembelajaran kooperatif tipe numbered head together (NHT) untuk meningkatkan hasil belajar kimia siswa kelas XI IPA 1 SMA negeri 3 Watampone (studi pada materi pokok struktur atom, sistem periodik unsur dan bentuk molekul). Jurnal Chemica, 17(1), 1-13. 